\title{
Efektivitas Ekstrak Serai Wangi (Cimbopogon nardus L.) sebagai Larvasida Nyamuk Aedes aegypti \\ (The Effectiveness of Citronella Extract (Cymbopogon nardus) as Larvaside of Aedes aegypti)
}

\author{
Makkiah*), Christina L Salaki **), Berty Assa \\ Program Studi Entomologi Pascasarjana Universitas Sam Ratulangi \\ Manado, 95155 \\ *Email: khiaimoet@gmail.com, \\ ${ }^{\star *}$ Email korespondensi: christinasalaki@ymail.com
}

(Article History: Received 20-10-2019; Revised 27-11-2019; Accepted 30-12-2019)

\begin{abstract}
Abstrak
Pengendalian nyamuk sebagai vektor utama penularan penyakit DBD hanya dapat dilakukan dengan cara memutuskan rantai penularannya melalui pengendalian nyamuk. Pengendalian nyamuk dapat dilakukan pada tahap larva dengan menggunakan biolarvasida yang terbuat dari bahan alami dan salah satunya adalah dengan menggunakan ekstrak kasar dari tanaman serai wangi (Cymbopogon nardus). Penelitian ini bertujuan untuk menguji efektivitas ekstrak serai wangi sebagai larvasida larva Aedes aegypti instar III dan IV. Penelitian ini adalah penelitian eksperimental menggunakan rancangan acak lengkap. Larva yang digunakan adalah larva instar III dan IV, dengan perlakuan konsentrasi ekstrak serai wangi $20 \%, 30 \%$, $40 \%$, dan $50 \%$ dalam $250 \mathrm{ml}$ air. Pada penelitian ini terdapat kontrol yaitu aquades yang tidak ditambahkan larutan apapun. Pengamatan kematian larva dilakukan pada jam ke 1, 3, 6, 12, 24, dan jam ke 48 dengan replikasi sebanyak 4 kali. Data presentase mortalitas larva digunakan untuk menghitung nilai $L C_{50}$ dan $L T_{50}$ dengan menggunakan analisisi Probit. Hasil penelitian menunjukkan ekstrak serai wangi efektif dalam mematikan $50 \%$ dari populasi larva uji dengan nilai $L C_{50}$ pada konsentrasi $36,48 \%$ serta waktu yang di butuhkan untuk mematikan $50 \%$ populasi larva uji adalah 10,45 jam.
\end{abstract}

Kata kunci : Ekstrak, Cymbopogon nardus, larvasida, Aedes aegypti

\begin{abstract}
Control of mosquitoes as the main vector of transmission of DHF can only be done by breaking the chain of transmission through mosquito control. Mosquito control can be carried out at the larval stage by using biolarvasides made from natural materials, one of which is by using a crude extract from the citronella plant (Cymbopogon nardus). This research is to find out the effectiveness of citronella extract as larvae of Aedes aegypti larvae instar III and IV. This research is a pure experimental study using a complete random design. The larvae used were instar larvae III and IV, with the treatment of citronella extract concentration of $20 \%, 30 \%, 40 \%$, and $50 \%$ in $250 \mathrm{ml}$ of water. In this study, there was a control i.e. aquades which did not add any solution. Observation of larvae death was done at 1 hour, 2 hours. 4 hours, 12 hours, 24 hours and 28 hours with replication 4 times. Data on larval mortality were used to calculate LC50 and LT 50 values using Probit regression analysis. The results showed that citronella extract was effective in killing $50 \%$ of the population of test larvae with LC50 values at a concentration of $36.48 \%$ and the time needed to kill $50 \%$ of the population of test larvae was 10,450 hours.
\end{abstract}

Keywords: Extract, Cymbopogon nardus, larvasida, Aedes aegypti

\section{PENDAHULUAN}

Demam Berdarah Dengue (DBD) tergolong penyakit infeksi yang disebabkan oleh virus Dengue yang ditularkan melalui tusukan nyamuk Aedes Aegypti. Ciri penyakit tersebut demam tinggi mendadak disertai manifestasi perdarahan dan bertendensi menimbulkan renjatan (shock) dan kematian (Ditjen P2PI 2011). DBD merupakan salah satu masalah kesehatan utama di Indonesia, karena dapat menyebabkaan kematian. DBD bersifat endemis, timbul sepanjang tahun disertai dengan Kejadian Luar Biasa (KLB). 
Sampai sekarang penyakit DBD belum ditemukan obat maupun vaksinnya, sehingga satu-satunya cara untuk mencegah terjadinya penyakit ini dengan memutuskan rantai penularan yaitu dengan pengendalian vektor (Koneri dan Pontororing 2016).

Selama ini pengendalian nyamuk sebagai vektor penyakit umumnya dilakukan dengan menggunakan insektisida sintetik. Hal ini dikarenakan bahan tersebut dianggap efektif, praktis, manjur, dan dari segi ekonomi lebih menguntungkan. Namun, hal ini perlu diwaspadai karena penggunaan insektisida sintetik secara terus menerus akan menimbulkan pencemaran lingkungan, kematian berbagai makhluk hidup lain dan menyebabkan larva menjadi resisten. Penggunaan insektisida sintetik juga dapat menyebabkan mutasi gen pada spesies tersebut (Widiyanti dan Mulyadiharje 2004). Insektisida sintetik bersifat bioaktif, mengandung bahan kimia yang sukar mengalami degradasi di alam sehingga residunya dapat mencemari lingkungan bahkan menurunkan kualitas lingkungan (Yunita 2009).

Melihat kerugian berupa efek samping yang ditimbulkan oleh insektisida sintetik, maka dibutuhkan bahan alternatif yang lebih ramah lingkungan tetapi juga efektif dalam mengendalikan populasi nyamuk Aedes aegypti. Alternatif yang dapat dilakukan adalah penggunaan insektisida nabati. Salah satunya adalah dengan memanfaatkan serai wangi (Cymbopogon nardus).

Saat ini insektisida nabati telah banyak memberikan kontribusi yang bermakna untuk alternatif baru dalam meningkatkan kesehatan masyarakat terutama dalam menurunkan jumlah penyakit yang banyak ditimbulkan oleh vektor nyamuk (Boesri et al. 2015). Beberapa penelitian tentang insektisida nabati dari serai wangi yang telah dilakukan diantaranya menggunakan ekstrak serai wangi dan biji mahoni (Swietenia macrophyla) dengan berbagai macam pelarut (Amirullah et al. 2018). Penelitian lainnya adalah penggunaan ekstrak serai wangi (Cymbopogon nardus) dengan pelarut methanol membunuh larva Aedes aegypti (Arcani et al. 2017).
Bagaimana efektivitas ekstrak $C$. nardus yang dibuat secara sederhana dengan menggunakan pelarut air sebagai larvasida nyamuk $A e$. aegypti belum pernah diteliti dan dilaporkan. Penelitian ini bertujuan untuk menguji efektivitas ekstrak serai wangi (Cymbopogon nardus) sebagai larvasida Aedes aegypti instar III dan IV.

\section{METODE}

Penelitian ini merupakan penelitian experimen murni (true eks-periment) menggunakan rancangan post test only control group yaitu suatu rancangan percobaan yang terdiri dari dua kelompok yaitu kelompok kontrol dan kelompok eksperimen. Rancangan penelitian menggunakan Rancangan Acak Lengkap (RAL) yang terdiri dari 4 perlakuan dengan konsentrasi tertentu.

Perlakuan hanya diberikan pada kelompok eksperimen, kelompok kontrol berisi larutan aquades. Masing-masing perlakuan diulang sebanyak empat kali. Pada penelitian ini terdapat variable bebas yaitu ekstrak $C$. nardus dan variable terikat yaitu jumlah larva Ae. aegypti instar III dan IV yang mati karena pemberian ekstrak $C$. nardus.

\section{Perbanyakan larva Aedes aegypti}

Telur nyamuk $A e$ aegypti diletakkan di nampan plastik yang berisi air untuk pemeliharaan larva. Telur menetas menjadi larva dalam waktu 1-2 hari. Larva akan berkembang dari instar I sampai instar III selama 4-5 hari. Pada masa perkembanganya, larva diberi makan berupa pelet ikan. Pada saat larva sudah mencapai instar III, larva tersebut dipindahkan ke dalam gelas plastik yang berisi larutan ekstrak serai wangi dengan berbagai konsentrasi.

\section{Ekstraksi batang serai wangi}

Serai wangi yang diambil dari daerah Tomohon, dipisahkan dari akar dan daunnya kemudian dicuci dan ditiriskan. Batang serai dipotong kecil-kecil lalu ditimbang sebanyak 250gr. Kemudian diblender dengan mencampurkan air sebanyak $250 \mathrm{ml}$. Hasil blender kemudian disaring dan diendapkan selama satu hari lalu, dipisahkan dari endapannya hingga didapatkan ekstrak. 


\section{Uji eksplorasi}

Uji ini bertujuan untuk memastikan ekstrak serai wangi bersifat toksik dan untuk mengetahui konsentrasi dari larutan yang dapat menyebabkan mortalitas hewan uji sebanyak 50 \%. Ekstrak serai wangi dibuat dengan konsentrasi $30 \%$, $40 \%, 50 \%$, dan $60 \%$ dengan volume $250 \mathrm{ml}$ air di dalam gelas plastik, kemudian 25 ekor larva $A e$ aegypti dimasukkan ke dalam laruran tersebut. Selanjutnya dilakukan pengamatan dan dihitung jumlah larva yang mati setelah 1 jam, 3 jam, 6 jam, 12 jam, 18 jam, 24 jam dan 48 jam setelah perlakuan.

Kriteria larva mati yaitu jika larva tidak bergerak dan tidak memberikan respon saat disentuh. Konsentrasi yang dipilih untuk mencari nilai $\mathrm{LC}_{50}$ pada tahap uji toksisitas yaitu konsentrasi terendah dari uji eksplorasi dan kemudian diletakkan diantara minimal 2 perlakuan yaitu 1 diatasnya dan 1 di bawahnya (Hanafiah 2008).

\section{Uji Efektivitas}

Hasil uji eksplorasi dilanjutkan dengan uji toksisitas. Uji ini dilakukan dengan ekstrak serai wangi diencerkan dengan konsentrasi $20 \%, 30 \%$, 40\% dan 50\% dengan volume $250 \mathrm{ml}$. Sebanyak 25 ekor larva instar III dimasukkan ke dalam larutan tersebut lalu dihitung mortalitas setelah 1 jam, 3 jam, 6 jam, 12 jam, 18 jam, dan 24 jam setelah perlakuan. Perlakuan yang sama diulangi sebanyak 4 kali (WHO 2005). Uji efektifitas ini dilakukan untuk mengetahui daya bunuh dari ekstrak serai wangi terhadap larva Ae. aegyptidengan menentukan nilai $\mathrm{LC}_{50}$ (Letal Consentration 50), dan $\mathrm{LT}_{50}$ (Lethal Time 50) dengan menggunakan analisis Probit. Untuk mengetahui presentase kematian larva uji dihitung menggunakan rumus:

Presentase Mortalitas $=$ $\frac{\text { Rata-rata kematian larva uji }}{\text { Jumlah larva uji }} \times 100 \%$

\section{Analisis Data}

Data yang diperoleh dari hasil pengamatan diuji menggunakan software uji analisis statistik SPSS. Tahap pertama analisis dilakukan dengan uji normalitas (Shapiro-Wilk) yang mendapatkan hasil sebaran data tidak normal, kemudian dilanjutkan dengan uji efek antara variabel subyek yang kemudian dilanjutkan Post Hoc tes yang menghasilkan nilai $p<0,05$. Untuk mengetahui dosis konsentrasi yang efektif menyebabkan mortalitas larva sebanyak $50 \% \quad\left(\mathrm{LC}_{50}\right)$ dan untuk mengetahui LT 50 , yaitu waktu yang dibutuhkan untuk mematikan larva sebanyak 50\%,dilakukan analisis Probit.

\section{HASIL DAN PEMBAHASAN Uji eksplorasi}

Hasil uji eksplorasi didapatkan bahwa semua konsentrasi ekstrak mampu menyebabkan mortalitas pada larva uji (Tabel 1). Hal ini menunjukkan dan memastikan bahwa ekstrak serai wangi tersebut bersifat toksik.

Tabel 1. Hasil uji pendahuluan efektivitas ekstrak serai wangi sebagai larvasida nyamuk Aedes aegypti selama 24 jam

\begin{tabular}{lcc}
\hline Konsentrasi & $\begin{array}{c}\text { Jumlah } \\
\text { larva mati }\end{array}$ & $\%$ \\
\hline Kontrol & 0 & 0 \\
$30 \%$ & 12 & 48 \\
$40 \%$ & 21 & 84 \\
$50 \%$ & 25 & 100 \\
$60 \%$ & 25 & 100 \\
\hline
\end{tabular}

Ekstrak tersebut mampu menyebabkan kematian $48 \%$ hewan uji pada konsentrasi $30 \%$ dan mampu membunuh $100 \%$ hewan uji pada konsentrasi $50 \%$ dan $60 \%$. Konsentrasi yang dipilih untuk mencari nilai LC $_{50}$ pada tahap uji toksisitas yaitu $20 \%$, $30 \%, 40 \%$, dan50\%. Konsentrasi ini dipilih karena perlakuan yang diperkirakan akan berpengaruh paling baik (konsentrasi $30 \%$ ) harus diletakkan diantara minimal dua perlakuan lainnya (Hanafiah 2008).

\section{Uji efektivitas serai wangi sebagai Larvasida larva Aedes aegypti.}

Berdasarkan hasil pengamatan mortalitas larva pada uji efektifitas serai wangi, diperolah distribusi kumulatif mortalitas larva dengan waktu pengamatan 
sampai 24 jam pada masing-masing perlakuan (Gambar 1). Perubahan jumlah mortalitas larva yang signifikan pada setiap pengulangan. Semakin tinggi konsentrasi larutan uji, semakin tinggi pula prosentasi kematian larva. Hal ini akibat dari semakin banyaknya senyawa alami yang masuk kedalam tubuh larva. Prosentasi mortalitas larva yang berbeda pada masing-masing konsentrasi dan lama waktu paparan terjadi karena masing-masing larva memiliki daya proteksi yang berbeda terhadap racun.

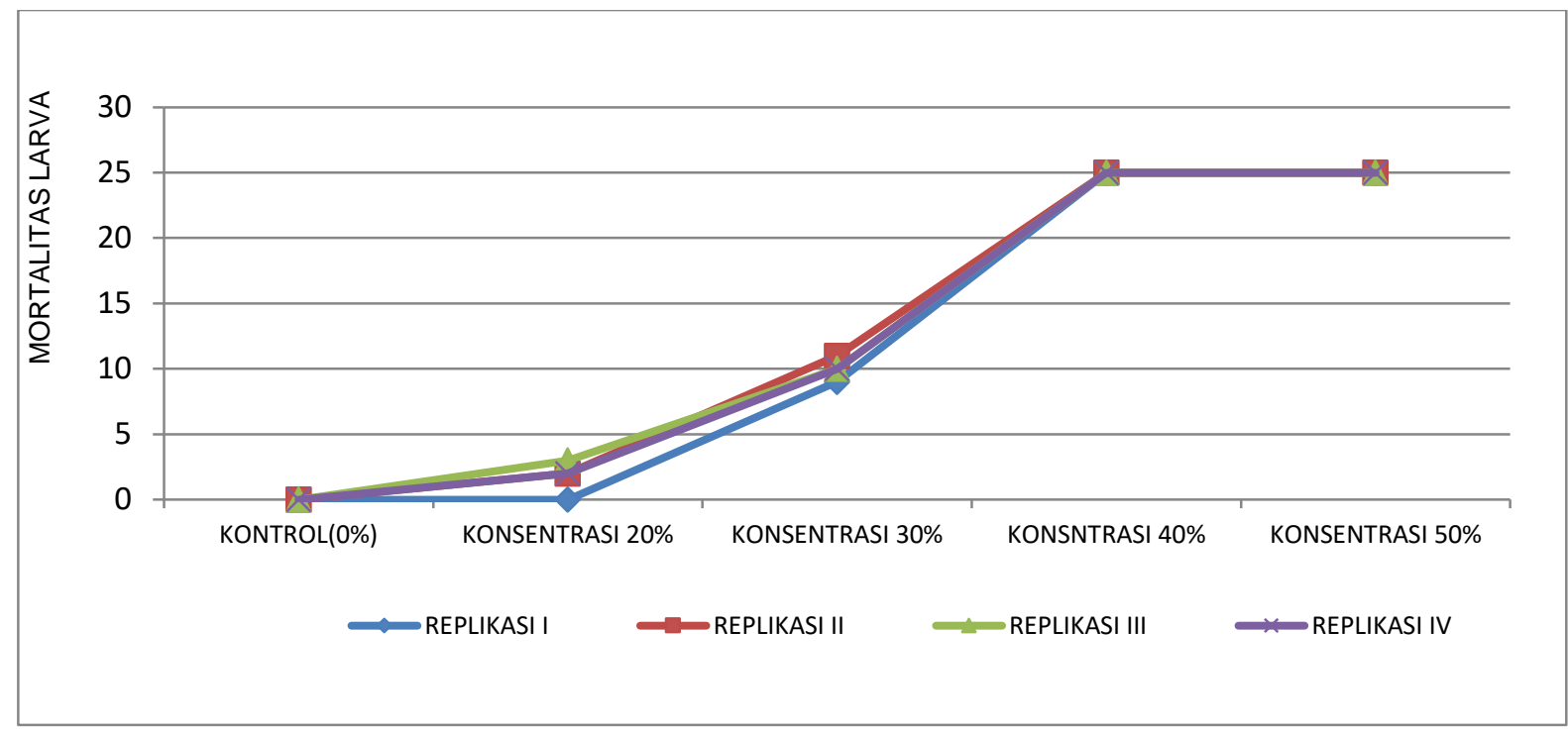

Gambar 1. Prosentase mortalitas larva uji pada setiap perlakuan konsentrasi dan replikasi (ulangan)

Pengulangan (replikasi) pada masingmasing perlakuan tidak memberikan pengaruh yang signifikan. Hasil uji normalitas dengan nilai $\mathrm{p}<0,05$ yang berarti bahwa distribusi data tidak normal. Selanjutnya dilakukan uji efek antara variabel subyek yang menunjukkan bahwa larutan ekstrak serai wangi berpengaruh secara nyata terhadap mortalitas larva instar III dan IV nyamuk Aedes aegypti. Hal ini dapat dilihat dari nilai signifikan variabel konsentrasi $p=0.000$, artinya variasi konsentrasi berpengaruh terhadap mortalitas larva, dan nilai signifikan Variabel ulangan $\mathrm{p}=0.993$, artinya ulangan tidak berpengaruh terhadap mortalitas larva.

Hasil uji lanjut (post hoc test) terdapat perbedaan yang signifikan antara perlakuan konsentrasi ekstrak serai wangi terhadap rata-rata mortalitas larva yaitu pada konsentrasi $20 \%, 30 \%, 40 \%$ dan $50 \%$. Hal ini berarti keempat konsentrasi tersebut memberikan pengaruh yang berbeda terhadap rata-rata mortalitas larva Aedes aegypti. Sedangkan pada konsentrasi $0 \%$ (kontrol) tidak memberikan pengaruh pada mortalitas larva. Konsentrasi yang paling berpengaruh pada mortalitas larva yaitu konsentrasi $40 \%$ dan $50 \%$ karena pada konsentrasi tersebut prosentase mortalitas larva paling tinggi dibandingkan dengan konsentrasi lain.

Hasil analisis probit untuk mendapatkan nilai $\mathrm{LC}_{50}$ didapatkan pada konsentrasi $36,48 \%$, yang artinya bahwa konsentrasi yang dapat menyebabkan mortalitas larva uji sebanyak $50 \%$ ada pada larutan dengan konsentrasi 36 , 48\%. Menurut WHO (2005) bahwa konsentrasi larvasida dianggap efektif apabila dapat menyebabkan kematian larva uji antara 10$95 \%$.

Berdasarkan data waktu yang dibutuhkan untuk mematikan larva uji dilkukan uji regresi linear sederhana untuk mengetahui nilai $\mathrm{LT}_{50}$. Hasil uji didapatkan nilai $\mathrm{LT}_{50}$ dari total waktu pengamatan adalah pada jam ke 10.45. Hal Ini berarti bahwa waktu yang dibutuhkan untuk 
mematikan $50 \%$ dari total populasi larva uji adalah 10,45 jam .

Ekstrak yang dibutuhkan untuk mematikan $100 \%$ hewan uji dalam penelitian ini lebih tinggi dibandingkan dengan berbagai hasil penelitian lainnya. Hasil penelitian Rizqia et al. (2016) melaporkan bahwa ekstrak etanol serai wangi dengan konsentrasi $0,0007 \mathrm{~g} / \mathrm{ml}$ mampu mematikan 94,67\% larva uji. Penelitian Arcani et al. (2017) mendapatkan konsentrasi $25 \%$ dengan paparan 60 menit adalah konsentrasi ekstrak serai wangi yang paling efektif dalam mematikan larva. Berbeda pula dengan hasil penelitian Amirullah et al (2018) yang mendapatkan konsentrasi $4,5 \%$ yang evektif mematikan $98 \%$ larva uji.

Perbedaan hasil ini diduga karena adanya perbedaan kadar kandungan senyawa yang terdapat dalam ekstrak serai wangi yangg menggunakan pelarut yang berbeda (Etanol). Pada uji fitokimia ekstrak etanol serai wangi, selain mengandung beberapa senyawa metabolit sekunder juga didapatkan kandungan senyawa minyak atsiri yang diketahui mempunyai efek toksik yang lebih tinggi (Hendrik et al. 2013). Ekstrak yang digunakan pada penelitian ini adalah ekstrak serai wangi yang dibuat dengan metode yang masih sangat sederhana dengan menggunaakan pelarut air namun terbukti tetap efektif dalam membunuh larva.

Kematian hewan uji terjadi karena ketidak mampuan larva dalam mendetoksifikasi senyawa kimia yang terdapat dalam larutan ekstrak. Menurut Rita dan Ningtyas (2009) bahwa ekstrak serai wangi mempunyai kandungan metabolit sekunder yang bersifat polar antara lain tanin, saponin, steroid, flavonoid, minyak atsiri dan beberapa zat aktif lainnya yang menyebabkan larutan ini bersifat toksik/racun. Racun ini digolongkan dalam racun kontak dan racun perut. Sebagai racun kontak, selain menyebabkan efek lokal ditempat kontak, suatu toksikan akan menyebabkan kerusakan mukosa kulit dan sebagai racun perut akan mengakibatkan gangguan sistem pencernaan larva sehingga gagal berkembang dan akhirnya mati (Suyanto 2009) .
Uji toksisitas dalam penelitian ini dilakukan dengan memasukkan larva nyamuk kedalam larutan ekstrak dengan konsentrasi tertentu, dengan demikian seluruh tubuh larva nyamuk akan terpapar oleh zat toksik dari ekstrak serai wangi. Senyawa zat toksik yang terkandung dalam larutan ekstrak serai wangi dapat masuk melalui mulut karena larva biasanya mengambil makanan dari tempat hidupnya (Yunita 2009). Dinding tubuh serangga merupakan bagian tubuh serangga yang dapat menyerap zat toksik dalam jumlah besar (Cania 2013).

Larva instar III dan IV dipilih sebagai hewan uji karena sudah mempunyai kemampuan yang lebih kuat dalam menetralisir senyawa yang bersifat toksik dibandingkan dengan larva instar I dan II. Berdasarkkan hasil ini maka diasumsikan bahwa dosis yang mampu mebunuh larva instar III dan IV juga mampu membunuh larva I dan II, sehingga LC yang didapatkan akan sesuai dengan target penelitian yaitu mampu membunuh semua larva (Dzakaria 2004).

\section{KESIMPULAN}

Ekstrak serai wangi ( $C$. nardus) efektif dalam mematikan larva Aedes aegypty instar III dan IV. Nilai LC $_{50}$ setelah 24 jam paparan pada konsentrasi $36,48 \%$. Hal ini berarti bahwa ekstrak serai wangi dengan konsentrasi 36,38\% mampu menyebabkan $50 \%$ mortalitas dari populasi larva uji. Nilai $\mathrm{LT}_{50}$ adalah 10,45 jam yang berarti bahwa waktu yang dibutuhkan untuk mematikan $50 \%$ dari populasi larva uji adalah 10,45 jam.

\section{DAFTAR PUSTAKA}

Amirullah, Nurhayu M, Eis N (2018) Uji efikasi ekstrak daun sereh (Andropogon nardus) dan biji mahoni (Swietenia macrophylla) terhadap mortalitas larva nyamuk Aedes aegypti. Biowallacea 5 (2): 838-852

Arcani, NLKS, Sudarmaja, IM, Swastik IK (2017) Efetifitas ekstrak etanol serai wangi (Cymbopogon nardus) sebagai Larvasidan Aedes Aegypti. E-Journal Medical 6 (1): 1-4

Boesri $\mathrm{H}$, Heriyanto B, Handayani SW, Suwaryono T (2015) Uji toksisitas 
beberapa ekstrak tanaman terhadap larva Aedes aegypti vektor demam berdarah dengue. Vektora 7(1): 29-38

Cania, E (2013) Efektivitas larvasida ekstrak daun legundi (Vitex trifolia) terhadap larva Aedes aegypti. Medical of Journal Lampung Uniiversity 2 (4): 52-60

Direktorat Jenderal Pengendalian P2PL, Kementerian Kesehatan Republik Indonesia (2011) Modul pengendalian demam berdarah dengue. Ditjen P2PL Kemenkes RI, Jakarta.

Dzakaria, S (2004) Pendahuluan entomologi parasitologi kedokteran edisi ke-3. Fakultas Kedokteran Universitas Indonesia, Jakarta.

Gritter RJ, Bobbit JM, Schwarting JM (1991) Pengantar kromatografi, Penerbit ITB, Bandung.

Hanafiah K (2008) Rancangan percobaan aplikatif: Aplikatif kodisional bidang pertamanan, peternakan, perikanan, industri, dan hayati. PT. RajaGrafindo Persad, Jakarta.

Harfiani, H (2012) Efektifitas larvasida ekstrak daun sirsak dalam membunuh jentik nyamuk. Jurnal Kesehatan Masyarakat 7(2): 164-169

Hendrik GW, Erwin, Pangabean AS (2013) Pemanfaatan tumbuhan serai wangi (Cymbopogon nardus) sebagai antioksidan alami. Jurnal Kimia Mulawarman 10 (2): 74-79,

Koneri R, Pontororing HH (2016) Uji ekstrak biji mahoni (Swietenia macrophylla) terhadap larva Aedes aegypti vektor penyakit demam berdarah. Jurnal Media Kesehatan
Masyarakat Indonesia 12 (4): 216223.

Rita E, Ningtyas DR (2009) Pemanfaatan Cymbopogon nardus sebagai larvasida Aedes aegypti. Jurusan Pendidikan Biologi, IKIP PGRI Semarang.

Rizkia GN, Ismawati, Yulianto FA (2016) Pengaruh ekstrak ethanol daun serai wangi terhadap kematian larva Aedes aegypti. Prosiding Pendidikan Dokter 2 (1): 844-849.

Suyanto $F$ (2009) Efek larvasida ekstrak kulit buah manggis (Garcinia mangostana L.) terhadap larva Aedes aegypti L. Skripsi. Fakultas Kedokteran Universitas Sebelas Maret, Solo.

WHO: World Health Organization (2005) Comunicable desease control guidelines for laboratory and field testing of mosquito larvicides. World Health Organization Communicable Disease Control, Prevention and Eradication Who Pesticide Evaluation Scheme WHO, Library Cataloguing-inPublication Data.

Widiyanti, NLM, Mulyadiharje S (2004) Uji toksisitas jamur Metarliizium anisopliae terhadap larva nyamuk Aedes aegypti. Media Litbang Kesehatan14(3): 25-31.

Yunita EA, Nanik HS, Jafron WH (2009). Pengaruh ekstrak daun teklan (Euphatorium riparium) terhadap mortalitas dan perkembangan larva Aedes aegypti. BIOMA 11 (1): 11-17 